\title{
ANALISIS PEMAHAMAN KONSEP GERAK PADA SISWA YANG DIAJAR DENGAN MEDIA VIDEO BERBANTUAN SOFTWARE TRACKER
}

\author{
Nur Utami Amaliah, Sahrul Saehana, dan I Wayan Darmadi \\ Jurusan Pendidikan MIPA \\ Fakultas Keguruan dan IImu Pendidikan Universitas Tadulako Palu
}

\begin{abstract}
Abstrak - Tujuan penelitian ini yaitu untuk mengetahui dan menganalisis pemahaman konsep gerak pada siswa yang diajar dengan media video berbantuan Software Tracker. Penelitian ini merupakan penelitian deskriptif kualitatif. Subjek penelitian merupakan siswa kelas X SMA Negeri 5 Palu semester II tahun ajaran 2017/2018. Responden dipilih berdasarkan subjek dalam kategori tinggi, sedang, dan rendah yang bersedia melakukan tes wawancara. Instrumen penelitian yang digunakan berupa tes pilihan ganda beralasan disertai Certain of Rensponse Index (CRI) yang diberikan sebelum dan setelah menggunakan media video berbantuan Software Tracker. Hasil penelitian menunjukkan bahwa pemahaman konsep gerak siswa pada tes awal dapat dikategorikan rendah. Pemahaman konsep gerak siswa setelah penggunaan media video berbantuan Software Tracker meningkat dan dapat dikategorikan sedang.
\end{abstract}

Kata Kunci: pemahaman konsep, gerak, media video, software tracker

\section{PENDAHULUAN}

Fisika adalah salah satu cabang ilmu alam untuk menjelaskan dan memahami fenomenafenomena yang terjadi di alam semesta berupa fakta, konsep, prinsip, dan hukum. Oleh karena itu, pembelajaran fisika di sekolah harusnya lebih menekankan pada proses penggalian konsep sehingga memberikan daya tarik bagi siswa. Namun kenyataan menunjukkan pembelajaran fisika lebih menekankan pada rumus dan teori dari buku pegangan yang digunakan. Akibatnya, siswa cenderung menghafal konsep fisika, dan memiliki pemahaman konsep fisika yang rendah [1].

Bloom [2] mendefinisikan pemahaman konsep sebagai kemampuan menangkap pengertianpengertian seperti mampu mengungkapkan suatu materi yang disajikan ke dalam bentuk yang lebih dipahami, mampu memberikan interpretasi, dan mampu mengaplikasikannya. Hal ini menjelaskan bahwa pemahaman konsep dalam pembelajaran fisika merupakan suatu hal yang sangat penting untuk dapat membelajarkan siswa secara maksimal dan bisa memperoleh hasil pembelajaran yang baik.

Miskonsepsi adalah akibat dari perhatian yang kurang terhadap pemahaman konsep fisika. Miskonsepsi sendiri merujuk kepada suatu konsep yang tidak sesuai dengan pengertian ilmiah, atau pengertian yang diterima para pakar dalam bidang itu. Penyebab miskonsepsi secara umum dapat berasal dari berbagai hal, seperti prakonsepsi awal, kemampuan, tahap perkembangan, minat, dan cara berpikir. Prakonsepsi atas konsep fisika yang dibangun oleh siswa itu sendiri melalui belajar informal dalam upaya memberikan makna atas pengalaman sehari-hari [3].

Berkaitan dengan itu, Suparno [3] mengungkapkan dari 700 studi mengenai konsep fisika, ada 300 diantaranya dalam mekanika; 159 tentang listrik; 70 tentang panas, optika, dan sifatsifat materi; 35 tentang bumi dan antariksa; serta 10 studi mengenai fisika modern. Hal ini menunjukkan bahwa jika terjadi miskonsepsi dalam fisika, maka mekanika berada di urutan teratas. Konsep mekanika sendiri mencakup konsep gerak; vektor; gaya, massa, dan berat; Hukum Newton; Kerja, kekekalan energi, dan momentum; serta mekanika fluida.

Fenomena gerak merupakan fenomena dalam konsep mekanika yang dapat dijumpai dengan sangat mudah pada kehidupan sehari-hari. Namun fenomena tersebut sangat sulit untuk dianalisis secara langsung, karena terjadi dalam waktu yang sangat singkat sehingga tidak banyak informasi yang bisa diperoleh dan siswa menjadi salah dalam memaknai fenomena tersebut.

Software Tracker adalah program analisis video yang khusus digunakan dalam pembelajaran fisika. Software ini dapat membantu siswa dalam menganalisis fenomena gerak sehari-hari yang telah terekam dalam bentuk media video. Hal ini juga untuk memudahkan siswa dalam memaknai peristiwa-peristiwa gerak yang terjadi disekitarnya [4]. 
Tujuan dari penelitian ini untuk mengetahui dan menganalisis pemahaman konsep gerak pada siswa yang diajar dengan media video berbantuan Software Tracker. Manfaat dari penelitian ini yaitu memberikan informasi mengenai pemahaman konsep gerak pada siswa yang diajar dengan media video berbantuan Software Tracker, serta memberikan informasi yang dapat digunakan untuk memperbaiki dan merencanakan program pembelajaran fisika di SMA, khususnya pada konsep gerak.

\section{METODE PENELITIAN}

Jenis penelitian ini merupakan penelitian deskriptif, penelitian ini berusaha untuk mendeskripsikan pemahaman konsep gerak pada siswa yang diajar dengan media video berbantuan Software Tracker berdasarkan fakta dan data yang diperoleh saat penelitian dilakukan.

Penelitian ini dilakukan di SMA Negeri 5 Palu dengan kelas $X$ MIPA 4 Semester II di tahun ajaran 2017/2018. Jumlah siswa di kelas X MIPA 4 yaitu 30 siswa, dijadikan sebagai subjek pada penelitian ini. Pemilihan lokasi penelitian dilandasi oleh kondisi lokasi yang sesuai dengan kriteria dalam penelitian, dimana siswa telah mempelajari konsep kinematika gerak. Selain itu, hasil observasi awal bersama guru fisika juga menjadi bahan petimbangan dalam pemilihan lokasi penelitian. Hasil obeservasi awal mengungkapkan bahwa pembelajaran fisika di sekolah cenderung pasif, dan hasil belajar siswa (ulangan harian) rendah, sehingga guru mengasumsikan bahwa pemahaman konsep siswa rendah.

Penelitian dilakukan dengan memberikan tes pemahaman konsep gerak. Selain itu juga digunakan lembar kerja siswa (LKS) saat praktikum dengan menggunakan media video berbantuan Software Tracker, dan wawancara langsung dengan beberapa siswa yang terpilih menjadi responden. Pada penelitian ini, tes pemahaman konsep dan wawancara dilakukan sebanyak 2 kali; tes dan wawancara awal untuk mengetahui konsepsi awal siswa; serta tes dan wawancara yang kedua yaitu untuk mengetahui pemahaman konsep siswa setelah praktikum menggunakan media video berbantuan Software Tracker.

Tes pemahaman konsep berupa tes pilihan ganda beralasan terbuka yang disertai dengan pemilihan skala Certanty Response Index (CRI). Skala CRI yang digunakan adalah skala 6 oleh Saleem [5]. Skala CRI disajikan pada Tabel 1.

TABEL 1 SKALA CERTAINTY RESPONSE INDEX (CRI)

\begin{tabular}{cl}
\hline CRI & Kriteria \\
\hline 0 & (Totally Guessed Answer): jika menjawab soal 100\% ditebak. \\
\hline 1 & (Almost Guess): jika menjawab soal persentase unsur tabakan antara 75\% - 99\% \\
\hline 2 & (Not Sure): jika menjawab soal persentase unsur tabakan $50 \%-74 \%$ \\
\hline 3 & (Sure): jika menjawab soal persentase unsur tebakan antara 25\% - 49\% \\
\hline 4 & (Almost Certain): jika menjawab soal persentase unsur tebakan antara 1\% - 24\% \\
\hline 5 & (Certain): jika menjawab soal tidak ada unsur tebakan sama sekali (0\%) \\
\hline
\end{tabular}

Data hasil tes pemahaman konsep dibuat dalam bentuk matriks, yangmana didasarkan pada kombinasi pilihan jawaban benar-salah, alasan benar-salah, serta nilai CRI tinggi-rendah. Kemudian penentuan atau klasifikasi siswa yang paham konsep, tidak paham konsep, dan miskonsepsi didasarkan oleh penentuan yang telah dikembangkan Hakim [6]. Penentuan deskripsi konsepsi siswa disajikan pada Tabel 2.

TABEL 2 PENENTUAN DESKRIPSI KONSEPSI SISWA

\begin{tabular}{clll}
\hline Jawaban & Alasan & CRI & \multicolumn{1}{c}{ Deskripsi } \\
\hline Salah & Salah & $<2,5$ & Tidak tahu konsep \\
\hline Salah & Benar & $<2,5$ & Tidak tahu konsep \\
\hline Salah & Salah & $>2,5$ & Miskonsepsi \\
\hline Salah & Benar & $>2,5$ & Miskonsepsi \\
\hline Benar & Salah & $<2,5$ & Tidak tahu konsep \\
\hline Benar & Benar & $<2,5$ & $\begin{array}{l}\text { Paham konsep, tapi } \\
\text { tidak yakin dengan } \\
\text { pilihan jawaban }\end{array}$ \\
\hline
\end{tabular}




\begin{tabular}{llll}
\hline Benar & Salah & $>2,5$ & Miskonsepsi \\
\hline Benar & Benar & $>2,5$ & Paham konsep \\
\hline
\end{tabular}

\section{HASIL DAN PEMBAHASAN}

\section{Hasil Penelitian}

Hasil penelitian ini diperoleh dari hasil tes pemahaman konsep siswa sebelum dan setelah menggunakan media video berbantuan Software Tracker. Adapun pemberian tes pada subjek dilakukan pada tanggal 11 dan 18 Mei 2018 di SMA Negeri 5 Palu.
1. Sebelum diajar dengan media video berbantuan Software Tracker.

a. Tes pemahaman konsep

Hasil analisis tes pemahaman konsep sebelum diajar dengan media video berbantuan Software Tracker dapat di lihat pada Tabel 3.

TABEL 3 ANALISIS PEMAHAMAN KONSEP GERAK PARABOLA DAN GERAK JATUH BEBAS SEBELUM DIAJAR DENGAN MEDIA VIDEO BERBANTUAN SOFTWARE TRACKER

\begin{tabular}{lccc}
\hline Konsep & $P$ & TP & $M$ \\
& $(\%)$ & $(\%)$ & $(\%)$ \\
\hline Gerak Parabola & 1,67 & 41,67 & 56,67 \\
\hline Gerak Jatuh Bebas & 13,33 & 50,00 & 36,67 \\
\hline
\end{tabular}

b. Wawancara

Hasil wawancara awal menunjukkan bahwa penyebab miskonsepsi karena adanya prakonsepsi awal siswa yang keliru, soal pemahaman yang salah dimengerti, serta pembelajaran di kelas yang cenderung memfokuskan pada rumus atau persamaan.
2. Setelah diajar dengan media video berbantuan Software Tracker.

Tes pemahaman konsep

Hasil analisis tes pemahaman konsep setelah diajar dengan media video berbantuan Software Tracker dapat di lihat pada Tabel 4.

TABEL 4 ANALISIS PEMAHAMAN KONSEP GERAK PARABOLA DAN GERAK JATUH BEBAS SETELAH DIAJAR DENGAN MEDIA VIDEO BERBANTUAN SOFTWARE TRACKER

\begin{tabular}{lccc}
\hline Konsep & $\mathrm{P}$ & $\mathrm{TP}$ & $\mathrm{M}$ \\
& $(\%)$ & $(\%)$ & $(\%)$ \\
\hline Gerak Parabola & 18,33 & 28,33 & 53,33 \\
\hline Gerak Jatuh Bebas & 68,33 & 26,67 & 5,00 \\
\hline
\end{tabular}

b. Wawancara

Penyebab terjadinya miskonsepsi yaitu prakonsepsi yang keliru, pembelajaran di kelas cenderung terfokus pada rumus dan persamaan, siswa tidak tahu menginterpretasi grafik, adanya kesalahan saat melakukan analisis pada Software Tracker, dan tampilan hasil analisis yang kurang jelas, serta siswa kurang memperhatikan saat melakukan praktikum.

\section{Pembahasan}

Berdasarkan hasil penelitian, dapat diketahui pemahaman konsep awal siswa tergolong rendah, baik pada konsep gerak parabola maupun pada konsep gerak jatuh bebas. Hal ini diakibatkan oleh siswa yang hanya mengamati dan kurang dalam hal menganalisis peristiwa gerak yang terjadi dalam kehidupan sehari-harinya, sehingga siswa kesulitan dalam memecahkan soal yang terkait dengan kehidupan sehari-hari.

Berdasarkan Tabel 3 pada hasil penelitian, diketahui bahwa pemahaman konsep gerak parabola lebih rendah daripada pemahaman konsep gerak jatuh bebas. Hal ini dikarenakan pada konsepsi awal, fenomena yang paling mudah untuk amati dan dipahami oleh siswa adalah fenomena gerak jatuh bebas. Sedangkan untuk fenomena gerak parabola, kebanyakan siswa hanya bisa mengamati tanpa bisa mememahami sehingga diperlukan alat bantu lain yang dapat menganalisis fenomena ini dengan lebih baik.

Sama halnya setelah diajar dengan media video berbantuan Software Tracker, pada Tabel 4, pemahaman konsep gerak jatuh bebas lebih baik dibandingkan dengan pemahaman konsep gerak 
parabola. Selain karena siswa yang tidak paham cara menginterpretasikan grafik, juga masih terdapat siswa yang mempertahankan konsepsi awal yang memang keliru. Habibulloh dan Madlazim [7] mengungkapkan kemampuan siswa dalam mengintrerpretasi grafik merupakan salah satu syarat dalam menggunakan Software ini, karena kebanyakan hasil analisis ditampilkan dalam bentuk grafik.

Sebelum dan saat setelah diajar dengan media video berbantuan Software Tracker, siswa yang mengalami miskonsepsi secara umum disebabkan karena adanya prakonsepsi awal yang keliru dan memilih untuk tetap mempertahankan konsepsi keliru tersebut walau telah melakukan praktikum di kelas. Hal ini, menjelaskan bahwa prakonsepsi awal siswa sangat mempengaruhi pemahaman konsep siswa kedepannya. Sebagaimana yang kemukakan oleh Suparno [3], pemahaman konsep dipengaruhi oleh prakonsepsi awal, kemampuan, tahap perkembangan, minat, dan cara berpikir, namun lebih cenderung pada prakonsepsi awal siswa. Hal ini menjelaskan bahwa prakonsepsi atas konsep fisika yang dibangun oleh siswa itu sendiri melalui pengalaman sehari-hari.

\section{KESIMPULAN DAN SARAN}

\section{Kesimpulan}

Pada konsep gerak parabola, pemahaman konsep awal, miskonsepsi, dan tidak paham konsep sebesar 1,67\%; 56,67\%; dan 41,67\%. Setelah menggunakan media video berbantuan Software Tracker terjadi peningkatan pemahaman konsep siswa sebesar 16,26\% disertai penurunan persentasi miskonsepsi dan tidak paham konsep masing-masing sebesar $13,34 \%$ dan $3,34 \%$.

Disisi lain, pada konsep gerak jatuh bebas pemahaman konsep awal, miskonsepsi, dan tidak paham konsep sebesar 13,33\%; 36,67\%; dan $50,00 \%$. Setelah menggunakan media video berbantuan Software Tracker terjadi peningkatan pemahaman konsep siswa sebesar \% disertai penurunan persentasi miskonsepsi dan tidak paham konsep masing-masing sebesar 23,33\% dan $31,67 \%$.

Penyebab terjadinya miskonsepsi yaitu prakonsepsi yang keliru, pembelajaran di kelas cenderung terfokus pada rumus dan persamaan, siswa tidak tahu menginterpretasi grafik, adanya kesalahan saat melakukan analisis pada Software Tracker, dan tampilan hasil analisis yang kurang jelas, serta siswa kurang memperhatikan saat melakukan praktikum.

\section{Saran}

Pada penelitian ini peneliti memberikan saran:

1. Penelitian ini agar dapat dilanjutkan dengan yang semisal mengenai konsep gerak parabola dan gerak jatuh bebas. Selain itu, penelitian ini juga dapat dikembangkan menggunakan materi gerak yang lainnya, dan konsep spectrum cahaya.

2. Hendaknya dalam proses belajar dan pembelajaran, pemahaman konsep tidak diabaikan. Siswa perlu dibiasakan untuk terlibat dalam kegiatan yang menuntut pemahaman konsep, terkhusus pada soalsoal yang mengakomodasi pemahaman konsep.

\section{DAFTAR PUSTAKA}

[1] Viajayani, E.R., Radiyono, Y., \& Rahardjo, D.T. "Pengembangan Media Pembelajaran Fisika Menggunakan Macromedia Flash Pro 8 pada Pokok Bahasan Suhu dan Kalor", Jurnal Pendidikan Fisika, Vol(1), pp. 144-155. April, 2013.

[2] Bloom, B.S., Engelhart, M.D., Furst, E.J., Hill, H.W, \& Krathwohl, D.R. "Taxonomy of Educational Objectives: Handbook 1, Cognitive Domain", New York: David Mckay, 1956.

[3] Suparno, P. 'Miskonsepsi dan Perubahan Konsep dalam Pendidikan Fisika", Jakarta: PT Grasindo, 2013.

[4] Aravind, V.R. "Video and Multimedia in Physics Education', Engineering and Physics Education, Vol(1), Issue 1, 2016.

[5] Salem, H., Bagayoko, D., \& Kelley, E.L. "Misconceptions and the Certainty of Response Index (CRI)", International Online Journal of Educational Sciences, Vol(4), pp. 294-299, 1999.

[6] Hakim, A., Liliasari, \& Kadarohman, A. "Student Concept Understanding of Natural Product Chemistry in Primary and Secondary Metabolites Using the Data Colecting Technique of Modified CRI", International Online Journal of Educational Sciences, Vol(4), pp. 544-553, 2012.

[7] Habibulloh, M., \& Madlazim "Penerapan Metode Analisis Video Software Tracker dalam Pembelajaran Fisika Konsep Gerak Jatuh Bebas untuk Meningkatkan 

dan Aplikasinya, Vol(4), pp. 544-533, 2014. 